\title{
MENINGKATKAN KESEHATAN MASYARAKAT DENGAN KEGIATAN SENAM PAGI DI DESA CINTA MAKMUR
}

\author{
Lisdiana $^{1}$, Khoirunnisa Siregar ${ }^{2}$, Rika Lestari $^{3}$, Mulkan Iskandar Nasution $^{4}$ \\ FITK, Universitas Islam Negeri Sumatera Utara, Medan \\ lisdiana476@gmail.com ${ }^{1}$,nisasiregar68@gmail.com² rikalestari1452000@gmailcom³
}

\begin{abstract}
Abstrak
Senam adalah latihan tubuh yang dipilih dan diciptakan dengan sengaja dan berencana, disusun secara sistematik dengan tujuan membentuk dan mengembangkan keseluruhan yang harmonis. Senam merupakan salah satu olahraga populer di masyarakat. Hasil dari kegiatan senam pagi pada bidang kesehatan masyarakat yang dilakukan mahasiswa KKN-DR Kelompok 99 yang telah dilaksanakan pada hari minggu tanggal 25 juli 2021 di Desa Cinta Makmur, Kecamatan Panai hulu, Kabupaten Labuhan Batu. Menjaga kesehatan jasmani sangatlah penting bagi manusia, terlebih lagi dimasa pandemi covid-19 ini. Dengan melakukan kegiatan senam pagi dapat memberikan manfaat yang baik bagi tubuh manusia dan merupakan salah satu cara kita menjaga daya imun agar tetap kuat dan terhindar dari berbagai virus termasuk virus covid-19. Seperti yang sudah di lakukan masyarakat di Desa Cinta Makmur yang mengikuti kegiatan senam pagidan merasa lebih baik setelah melakukan senam pagi.
\end{abstract}

Kata Kunci : Senam, Kesehatan, Daya Imun

\begin{abstract}
Abstrack
Gymnastics is a body exercise that is chosen and created deliberately and planned, systematically arranged with the aim of forming and developing a harmonious whole. Gymnastics is one of the most popular sports in society. The results of the morning gymnastics activities in the public health field carried out by KKN-DR Group 99 students which were carried out on Sunday, July 25, 2021 in Cinta Makmur Village, Panai Hulu District, Labuhan Batu Regency. Maintaining physical health is very important for humans, especially during this COVID-19 pandemic. By doing morning exercise activities, it can provide good benefits for the human body and is one way for us to keep our immune system strong and avoid various viruses including the covid19 virus. As has been done by the people in Cinta Makmur Village who take part in morning exercises and feel better after doing morning exercises.
\end{abstract}

Keywords: Gymnastics, Health, Immune Power

\section{PENDAHULUAN}

Menurut World Health Organization (WHO) kesehatan adalah suatu keadaan sehat yang utuh secara fisik, mental, dan sosial serta bukan hanya merupakan bebas dari penyakit. Olahraga dipilih karena merupakan kegiatan yang mudah dipraktikkan dan juga tidak memerlukan biaya yang besar, hanya adanya kemauan dalam melakukannya untuk menunjang kesehatan.(Dewi, 2012)

Kesehatan adalah harta yang paling berharga bagi tubuh kita, dengan berolahraga menjadikan kita senantiasa dalam keadaan bugar dan sehat (Aung et al., 2020). Karna olahraga merupakan suatu kegiatan jasmani yang dilakukan dengan maksud untuk memelihara kesehatan dan memperkuat otot-otot tubuh serta meningkatkan imun tubuh terutama pada masa pandemi Covid-19 diera PPKM ini.

Olahraga menurut (Giriwijoyo \& Sidik, 2013) terbagi menjadi empat macam yaitu olahraga prestasi, olahraga rekreasi, olahraga kesehatan dan olahraga pendidikan. Salah satu olahraga rekreasi adalah senam yang merupakan latihan tubuh yang dipilih dan diciptakan dengan berencana, disusun secara sistematis dengan tujuan membentuk dan mengembangkan pribadi secara harmonis. Mahendra, 2020 menjelaskan tujuan dari senam adalah meningkatkan daya tahan tubuh, kekuatan, kelentukan, kelincahan, koordinasi serta kontrol tubuh.(Herdiansyah et al., 2020)

Aktivitas olahraga yang dapat meningkatkan imun tubuh atau kesegaran jasmani adalah olahraga yang cukup memberikan beban kepada jantung dan paru. Aktivitas latihan fisik ringan lebih bermanfaat pada fungsi imunitas bila dibanding hanya melakukan aktivitas berupa duduk atau tidak melakukan kegiatan apapun. Kekebalan tubuh dapat mudah ditingkatkan dengan melakukan latihan fisik/olahraga juga istirahat serta tidur

Dipublikasikan Oleh :

UPT Publikasi dan Pengelolaan Jurnal

Universitas Islam Kalimantan Muhammad Arsyad Al-Banjari Banjarmasin 
cukup. Mekanisme kenaikan atau penurunan imun saat latihan fisik/olahraga dapat memberikan manfaat positif bagi kesehatan dalam jangka panjang, hal ini berkaitan dengan pertahanan tubuh terhadap infeksi penyakit. (Rifma, 2013)

Olahraga di masa corona ini menjadi suatu kebutuhan pokok. Olahraga dapat mengusir kebosanan di rumah, meningkatkan imunitas, mengisi waktu luang, dan meningkatkan energi dalam menjalani rutinitas sehari-hari. Kurangnya aktivitas fisikselama masa pandemi dapat meningkatkan risiko penyakit dan obesitas. Asupan makanan meningkat disertai aktivitas fisik berkurang akan meningkatkan obesitas Aktivitas fisik yang tepat dapat mengurangi stres dan kecemasan. Kadar endorfin akan meningkat setelah berolahraga. (Malm et al., 2019)

Pelaksanaan pengabdian melakukan aktivitas olahraga berupa senam umum yang dilakukan setiap hari minggu pagi oleh intrukstur profesional. Dengan senam umum diharapkan Imunitas warga akan meningkat, selain itu berolahraga senam umum, tim pengabdian memberikan edukasi terkait cara berolahraga yang baik dan benar-benar sesuai frekuensi, selain itu tim memberikan pemahaman kepada warga terkait pandemi agar masyarakat memiliki perilaku dan kebiasaan sehari-hari untuk menjaga kebersihan protokol kesehatan. (Rubiana et al., 2020)

Senam merupakan latihan tubuh yang dipilih dan diciptakan dengan sengaja dan berencana, disusun secara sistematik dengan tujuan membentuk dan mengembangkan keseluruhan yang harmonis. Senam merupakan kegiatan fisik yang paling kaya struktur geraknya. Jika dilihat dari taksonomi gerak umum, senam dapat secara lengkap diwakili oleh gerak-gerak dasar yang membangun pola gerak yang lengkap mulai pola gerak lokomotor, non lokomotor sampai kemanipulatif.(Juniarto et al., 2020)

Secara sosial, olahraga dapat digunakan sebagai media sosialisasi melalui interaksi dan komunikasi dengan orang lain atau lingkungan sekitar. Salah satu indikasi meningkatnya keinginan masyarakat akan derajat kesehatan yang tinggi, penampilan jasmani yang proporsional dan aktualisasi diri yang lebih luas dalam lingkungannya mencerminkan bahwa kebutuhan masyarakat semakin beragam sehingga membutuhkan tempat atau wahana yang dapat menyalurkan serta memenuhi kebutuhan tersebut.(Prasetyo, 2015)

Senam merupakan salah satu olahraga popular di masyarakat. Dengan mengetahui perubahan yang terjadi di tubuh, seseorang dapat merancang suatu program olahraga untuk mendapatkan perubahan optimal sesuai dengan yang diharapkan. Kesehatan Olahraga pada dasarnya mengkaji hubungan timbal balik antara Kesehatan dan Olahraga. Sasaran utamanya adalah bagaimana kesehatan mendukung prestasi olahraga, dan bagaimana olahraga mendukung derajad kesehatan seseorang. Sistim Kesehatan Nasional yang dianut di Indonesia pada hakekatnya adalah pencerminan upaya meningkatkan kemampuan setiap individu dan segenap masyarakat dalam memecahkan sendiri masalah kesehatannya menuju peningkatan derajad kesehatan tertentu. (Anggriawan, 2015)

Di masa pandemi Covid-19, banyak masyarakat yang mencari informasi mengenai cara mencegah virus korona dan usaha meningkatkan kekebalan tubuh. Sejak kasus pertama pada 2 Maret 2020 di Indonesia, hingga kini terus terjadi peningkatan jumlah positif Covid-19. Pemerintah membentuk Gugus Tugas Percepatan Penanganan Covid-19 untuk menekan penyebarannya. Namun, sebagai individu, kita juga perlu berbuat sesuatu untuk mencegah penyebaran virus ini. Untuk itulah edukasi pola hidup sehat kepada masyarakat sangat diperlukan.

Pola hidup sehat adalah gaya hidup yang memperhatikan segala aspek kondisi kesehatan,mulai dari makanan dan minuman,nutrisi yang dikonsumsi dan prilaku kita seharihari, baik itu dalam sebuah rutinitas olahraga yang tentu akan menjaga kondisi kesehatan dan juga akan menghindarkan dari segala hal yang dapat menjadi penyebab penyakit bagi tubuh kita,lebih-lebih kesehatan adalah dambaan kita semua.Untuk hidup sehat tentunya akan menjalankan sebuah aktifitas rutin dengan memperhatikan pola hidup sehat,kekayaan lahir dan batin tidak ada artinya bila kita masih terjebak dalam kondisi atau situasi sakit,baik itu karna tingkah laku yang tidak memperhatikan kondisi badan.

Pola hidup sehat adalah sebuah komitmen jangka panjang untuk menjaga dan melakukan beberapa hal agar mampu mendukung fungsi tubuh,sehingga berdampak baik bagi kesehatan.Menerapkan pola hidup sehat juga menjadi hal yang sangat penting, lebih di masa pandemi seperti ini,menjaga kesehatan dan imunitas tubuh menjadi hal yang utama dan paling utama untuk terhindar dari virus covid-19. Tujuan atau manfaat dari pola hidup sehat tentunya untuk menjaga kesehatan tubuh supaya tidak mudah sakit. Tapi menerapkan pola hidup sehat memiliki beberapa tujuan juga, misalnya; untuk mendapatkan kesehatan jasmani dan rohani dapat selalu terjaga dan supaya memiliki kesehatan mental yang stabil sehingga tidak mudah depresi ataupun stress.

Menurut Menkes (2020), yang perlu disadari benar adalah pentingnya menjaga kesehatan diri sendiri karena pencegahan tersebut adalah yang paling baik dan murah. Adapun langkah pencegahan dan menjaga diri dari Virus Corona adalah dengan menerapkan GERMAS (Gerakan Masyarakat Hidup Sehat). Pada awal

Dipublikasikan Oleh :

UPT Publikasi dan Pengelolaan Jurnal

Universitas Islam Kalimantan Muhammad Arsyad Al-Banjari Banjarmasin 
2020, dunia dikejutkan dengan mewabahnya pneumonia baru yang bermula dari Wuhan, Provinsi Hubei yang kemudian menyebar dengan cepat ke lebih dari 190 negara dan teritori. Wabah ini diberi nama coronavirus disease 2019 (COVID-19) yang disebabkan oleh Severe Acute Respiratory Syndrome Coronavirus-2 (SARSCoV-2). Penyebaran penyakit ini telah memberikan dampak luas secara sosial dan ekonomi. Masih banyak kontroversi seputar penyakit ini, termasuk dalam aspek penegakkan diagnosis, tata laksana, hingga pencegahan. Ratusan ribu manusia terinfeksi dan ribuan lainnya meninggal dunia. Untuk di Indonesia sendiri pemerintah telah memberikan himbauan-himbauan kepada masyarakat dalam mengatasi wabah ini agar berjalan efektif dan efisien. Tetapi pada kenyataannya masih banyak masyarakat Indonesia yang tidak mengindahkan himbauan ini.

Covd-19 atau sering disebut dengan virus corona merupakan keluarga besar virus yang menyebabkan penyakit pada manusia, biasanya menyebabkan gangguan pernafasan mulai dari flu biasa sampe dengan penyakit yang serius hingga menyebakan kematian.Berdasarkan artikel yang dikutip dari sellen salah satu dosen prodi teknologi pangan di ITERA menyampaikan bahwa: "di masa pandemi Covid-19, banyak masyarakat yang mencari informasi mengenai cara mencegah virus korona dan usaha meningkatkan kekebalan tubuh. Sejak kasus pertama pada 2 Maret 2020 di Indonesia, hingga kini terus terjadi peningkatan jumlah positif Covid-19. Pemerintah membentuk Gugus Tugas Percepatan Penanganan Covid-19 untuk menekan penyebarannya. Namun, sebagai individu, kita juga perlu berbuat sesuatu untuk mencegah penyebaran virus ini”.'(Asri et al., 2021, p. 57)

Virus tersebut dapat merusak jaringan pada paru sehingga terjadi pembengkakan yang membuat kesulitan bernapas dan dapat terjadi Acute Respiratory Distress Syndrome yang mengakibatkan pasien meninggal. Selain pada paru-paru, corona juga dapat menginfeksi organ lain contohnya pada saluran pencernaan. Gejala yang ditimbulkan bergantung seberapa kuatnya sistem imunitas.

Untuk itu menjaga kesehatan serta membiasakan pola hidup sehat menjadi hal yang utama untuk dilakukan ditatanan kehidupan fase new normal ini,namun di wilayah perdesaan yang terbilang jauh dari perkotaan masih mengabaikan bagaimana berperilaku pola hidup sehat di masa pendemi,dikarenakan kurangnya pemahaman masyrakat tentang covid-19 baik dari gejala dan dampak yang akan terjadi pada dirinya. Maka tidaklah heran jika di sebagian wilayah masih belum menerapkan pola hidup sehat. Untuk itu mengedukasi pola hidup sehat merupakan salah satu cara untuk menjaga dan memberikan pemahaman kepada masyarakat baik dengan cara memberikan contoh pola hidup sehat maupun dengan cara memberikan gambaran tentang pentingnya menjaga pola hidup sehat lebih-lebih dimasa pendemi covid- 19. Mengingat pentingnya menjaga kesehatan fisik lebih-lebih imunitas tubuh,sehingga olaharaga meruapakan salah satu cara untuk menghindari serangan covid-19.

Kegiatan ini dilakukan dengan melakukan sosialiasi serta cara memperaktikan cuci tangan yang benar pada masyarakat. Setelah dilakukan edukasi mengenai cara cuci tangan yang benar, sekarang masyarakat jadi lebih paham dan melakukannya setiap hari dan bahkan setiap saat jika mereka keluar dan pulang lagi setelah beraktivitas. Bahkan di setiap gang mereka bergotong royong untuk membeli wadah sebagai tempat cuci tangan.

Tujuan dilaksanakannya senam Pramuka ini ialah untuk salah satu pendekatan yang dillakukan oleh mahasiswa KKN-DR 99 kepada masyarakat guna melaksanakan kegiatan KKN dan untuk lebih meningkatkan kesehatan masyarakat di Desa Cinta Makmur.

\section{METODE}

Guna untuk terwujudnya tujuan dari kegaitan KKN DR kelompok 99. Di desa Cinta Makmur dilakukan kegiatan senam pagi kepada masyarakat setempat, khususnya para ibu-ibu dan bapak-bapak yang sudah tergolong lansia.

Metode yang dilakukan dengan penyuluhan. Kegiatan dimulai dari perancangan waktu, tempat, dan sasaran. Setelah itu pemberitahuan kepada Kadus-Kadus yang nanti akan membri info kepada masyarakatnya agar datang untuk kegiatan senam di lapangan sepak bola Cinta Makmur. Selanjutnya melaksanakan pelaksanaan sesuai dengan rencana yang di lakukan. Setelah kegiatan senam dilakukan wawancara untuk mengetahui apakah pelaksanaan senam pagi ini di implementasikan dalam kehidupan sehari-hari.

a) Waktu dan Tempat

Pelaksanaan Senam pagi yang dilakukan oleh Mahasiswa KKN-DR 99 pada Minggu, 25 Juli 2021 pukul 08.00 - selesai (WIB). Kegiatan senam ini dilakukan di lapangan bola desa Cinta Makmur Kecamatan Panai Hulu Kabupaten Labuhan Batu dan diikuti oleh masyarakat setempat.

b) Pendekatan

Pendekatan yang digunakan oleh mahasiswa KKN-DR 99 pangabdian adalah dengan pendekatan

Dipublikasikan Oleh : 
metode demonstrasi atau mempraktekan olahraga bentuk senam pramuka dengan menggunakan audiovisual youtube oleh 3 mahasiswa yang menjadi instruktur dan diikuti oleh peserta dan diampingi oleh mahasiswa peserta KKN lainnya.

c) Data

Data yang diperoleh oleh penulis yaitu melalui data kuesioner dan wawancara dari beberapa warga yang mengikuti kegiatan senam pagi.

d) Sasaran Makmur.

Sasaran dari kegiatan senam ini adalah Masyarakat yang termasuk orang tua sekitar di desa Cinta

\section{HASIL DAN PEMBAHASAN}

Hasil dari kegiatan KKN-DR Kelompok 99 yang telah dilaksanakanpada hari minggu tanggal 25 juli 2021 di Desa Cinta Makmur, Kecamatan Panai hulu, Kabupaten Labuhan Batu. Kegiatan ini termasuk kedalam bidang Kesehatan Masyarakat, pada bidang ini kami dari KKN-DR Kelompok 99 UINSU mengajak masyarakat agar ikut berpartisipasi dalam menjalakan program kerja kami tersebut.

Pada kegiatan senam ini masyarakat sangat antusias dalam mengikutinya, dan sebelumnya kami juga memberikan informasi terkait tentang pentingnya menjaga kesehatan tentunya menjaga imun tubuh agar tetap kuat dalam masa pandemi ini.

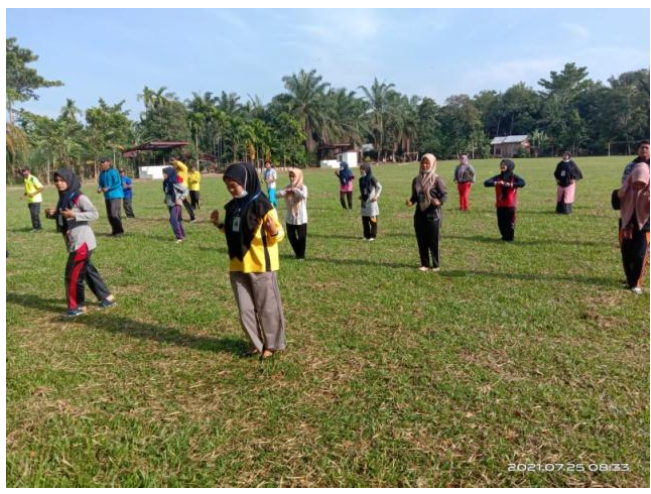

Gambar 1: Pelaksanaan Senam Pramuka.

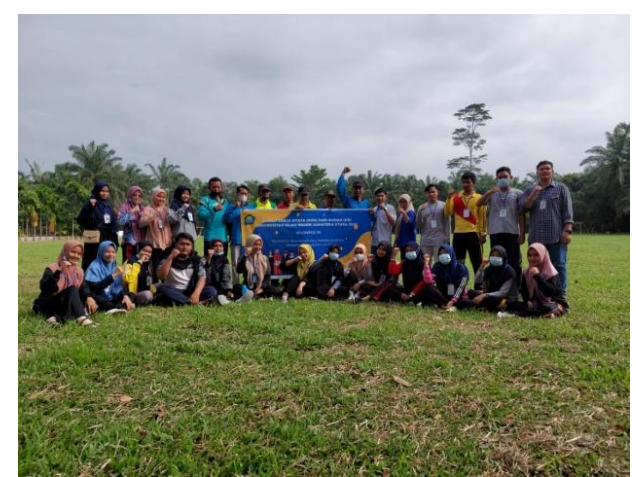

(Sumber: Tim KKN DR 99)

Gambar 2. Foto bersama masyarakat

(Sumber: Tim KKN DR 99)

Senam pagi yang kami lakukan pada Desa Cinta Makmur, Kecamatan Panai hulu, Kabupaten Labuhan Batu ini, adalah senam Pramuka. Kami dari KKN- DR kelompok 99 UINSU saat ini sedang aktif melakukan senam pagi bersama dengan masyarakat setempat. Dengan senam pagi ini diharapkan anak-anak KKN dapat mengajak masyarakat untuk ikut berpartisivasi dalam pelaksanaan senam pramuka yang dimana termasuk dalam suatu agenda atau prokerja.

Dengan adanya senam pagi ini kami mengajak masyarakat untuk menjaga imun agar tetap sehat dan menyadarkan masyarakat seberapa pentingnya senam pagi di masa pandemi ini, Selain menjaga imun kami KKN-DR kelompok 99 juga melakukan pendekatan kepada anak-anak sekitar, Ternyata meskipun pandemi, mereka tetap menjalankan aktivitas ini tanpa mengenal lelah. "Dari pada kita terus rebahan yang membuat suasana membosankan lebih baik kita mengisi waktu dengan senam pagi" ujar Budi Irawan sebagai ketua KKN- DR Kelompok 99 UINSU.

Dan tak lupa juga kami melakukan kegiatan senam dengan menjalankan protokol kesehatan dengan menjaga jarak, memakai masker, serta mencuci tangan sebelum dan sesudah kegiatan senam.

Kegiatan senam pagi ini cukup dilakukan sekali dalam seminggu danharus sesuai protokol kesehatan agar kita tidak menimbulkan kerumunan di Desa ini. Kita juga bisa melakukan senam pagi sendiri di rumah, yang paling terpenting ialah kesehatan kita harus tetap terjaga. Jadi, tetaplah kita menjaga kesehatan dan juga imun kita sebab dengan kita sehat apapun virusnya kita dapat mudah untuk menghindarinya.

"Kegaiatan senam yang diadakan oleh anak-anak Mahasiswa KKN ini sangat bagus, karena di era pandemi seperti sekarang ini memang dianjurkan banyak bergerak panasan agar tubuh tetap panas dan menambah imun, terlebih lagi orang- orang tua". Ujar bapak Sutres masyarakat setempat yang mengikuti kegiatan senam. 
Tingkat pengetahuan masyarakat di Desa Cinta Makmur, Kecamatan Panai Hulu, Kabupaten Labuhan Batu tentang kesehatan sudah cukup baik, oleh karena itu anak-anak KKN dengan mudah mengajak masyarakat untuk ikut berpartisipasi dalam kegiatan senam tersebut.

Kegiatan pengabdian ini dilakukan sebagai bentuk kesadaran akan pentingnya menjaga kesehatan dan kebugaran jasmani ditengah pandemi Covid-19 sebagai upaya agar terhindar dari infeksi virus (Muhammad, 2020).

Dari hasil angket yang kami berikan melalui media sosial berup whats app kepada beberapa masyarakat dananak-anak yang mengikuti senam didapatkan hasil:

1. Apakah anda mengikuti kegiatan senam pagi yang dilakukan oleh mahasiswa KKN-DR 99 yang dilaksanakan di desa anda?

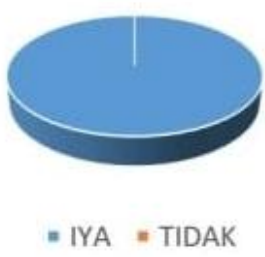

Dari grafik tersebut terdapat 29 orang ikut serta dalam kegiatan senam pagi yang di adakan KKN dr kelompok 99.

2. Apakah anda merasakan lebih baik ketika setelah melakukan senam pagi?

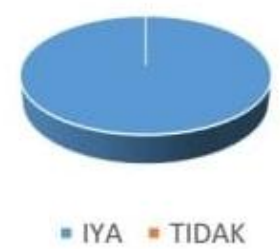

Dari grafik tersebut didapatkan hasil yaitu $100 \%$ masyarakat merasakan lebih baik setelah lakukan kegiatan senam pagi

3. Sebelum adanya kegiatan senam pagi yang dilakukan oleh Mahasiswa KKN- DR 99, apakah anda pernah melakukan olahraga lainnya?



Dari grafik tersebut didapatkan hasil yaitu sebanyak 14 orang $(48,3 \%)$ pernah melakukan olahraga lain dan sebanyak 15 orang $(51,7 \%)$ tidak pernah melakukan olahraga lain.

4. Senam pagi dapat memberi manfaat bagi tubuh kita? 


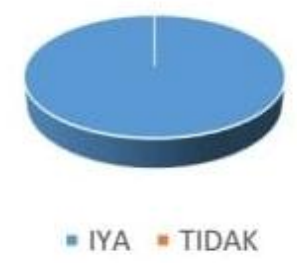

Dari grafik tersebut didapatkan hasil yaitu sebanyak $100 \%$ orang menyatakan bahwa senam pagi memberikan manfaat baik bagi tubuh kita.

5. Dimasa pandemi ini kita harus tetap menjaga kesehatan dengan beraktivitas sepeti senam pagi.

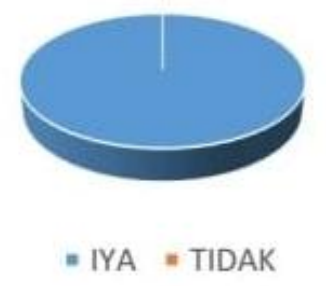

Dari grafik tersebut didapatkan hasil yaitu sebanyak $100 \%$ responden menjawab setuju bahwa kita harus tetap menjaga kesehatan dengan beraktivitas seperti senam pagi.

\section{UCAPAN TERIMAKASIH.}

Selanjutnya tak lupa kami ucapkan terimakasih kepada bapak Abdul Khalik Lubis selaku camat Panai Hulu, dan kami ucapkan terimakasih kepada bapak Ego Wiharno sebagai Kepala Desa yang sudah memberikan izin kepada kami untuk melaksanakan KKN di Desa Cinta Makmur Kecamatan Panai Hulu Kabupaten Labuhan Batu. Kami ucapkan terimakasih kepada guru mengaji di Desa Cinta makmur yang telah memberi kesempatan kepada kami selaku para mahasiswa/mahasiswi KKN untuk bias melakukan kegiatan ngajar mengajar di TPA tersebut.

Takluput juga kami ucapkan terimakasih kepada ketua remaja mesjid beserta jajarannya yang telah sudi kiranya membantu segala aspek kegiatan para peserta KKN. Dan ucapan terimakasih yang sedalamdalamnya untuk warga desa Cinta Makmur Kecamatan Panai Hulu Kabupaten Labuhan Batu yang begitu ramah dan menerima serta menyambut baik kedatangan kami. Tanpa adanya keramahan dan sambutan baik tersebut tentu saja kegiatan KKN yang kami lajukan tidak berjalan semestinya. Kami juga meminta maaf yang sebesar-besarnya apabila selama kegiatan KKN berlangsung ada suatu kejadian yang mengganggu atau meresahkan warga desa Cinta Makmur.

\section{PENUTUP}

Senam adalah bentuk latihan fisik yang secara sistematik disususn dengan gerakan-gerakan yang terpilih dan terencana untuk mencapai tujuan seperti daya tahan tubuh kekuatan, kelenturan, koordinasi, membentuk prestasi, membentuk tubuh yang ideal, dan memelihara kesehatan tubuh. Ternyata Masih banyak masyarakat yang belum pernah sama sekalian melakukan senam pagi. Masyarakat percaya bahwa senam pagi memiliki banyak manfaat bagi kesehatan setelah melakukan senam pagi. Aktivitas latihan fisik ringan lebih bermanfaat pada fungsi imunitas bila dibanding hanya melakukan aktivitas berupa duduk atau tidak melakukan apapun.

\section{REFERENSI}

Anggriawan, N. (2015). Peran Fisiologi Olahraga Dalam Menunjang Prestasi. Jurnal Olahraga Prestasi, 11(2), 114694. https://doi.org/10.21831/jorpres.v11i2.5724

Asri, I. H., Lestarini, Y., Husni, M., \& Yul, Z. M. (2021). Edukasi Pola Hidup Sehat Di Masa Covid-19. Jurnal Abdi Populika, 02(1), 56-63. https://e-journal.hamzanwadi.ac.id/index.php/abdipopulika/article/view/3105 
Aung, M. N., Yuasa, M., Koyanagi, Y., Aung, T. N. N., Moolphate, S., Matsumoto, H., \& Yoshioka, T. (2020). Sustainable health promotion for the seniors during COVID-19 outbreak: A lesson from Tokyo. Journal of Infection in Developing Countries, 14(4), 328-331. https://doi.org/10.3855/JIDC.12684

Dewi, K. S. (2012). BUKU AJAR KESEHATAN MENTAL.

Herdiansyah, D., Latifah, N., Yohsa Ibarahim, O., Kesehatan Masyarakat, F., Muhammadiyah Jakarta Alamat, U., \& Ahmad Dahlan, J. K. (2020). Implementasi Senam Penguin Sebagai Kegiatan Olahraga Rutin Santri Ponpes Sabilunajat Implementation of Pinguin Gymnastics As a Sport of Sabilunajat Santri Activities 1). 1, 7-10. https://jurnal.umj.ac.id/index.php/AS-SYIFA

Juniarto, M., Nurulfa, R., Jasmani, P., \& Jakarta, U. N. (2020). SOSIALISASI SENAM JANTUNG DALAM UPAYA MENINGKATKAN. 2020, 86-90.

Malm, C., Jakobsson, J., \& Isaksson, A. (2019). Physical activity and sports-real health benefits: A review with insight into the public health of sweden. Sports, 7(5). https://doi.org/10.3390/sports7050127

Prasetyo, Y. (2015). Kesadaran Masyarakat Berolahraga Untuk Peningkatan Kesehatan Dan Pembangunan Nasional. Medikora, 11(2), 219-228. https://doi.org/10.21831/medikora.v11i2.2819

Rifma. (2013). Problematika Kompetensi Pedagogik Guru Sekolah Dasar. Jurnal Media Ilmu Keolahragaan Indonesia, 5(2), 57-65. http://ejournal.unp.ac.id/index.php/pedagogi/article/view/2225

Rubiana, I., Mulyana, F. R., Herliana, M. N., \& Soraya, N. (2020). Meningkatkan Imunitas Tubuh Melalui Senam Umum Ditengah. Jurnal Pengabdian Kepada Masyarakat LPPM-Universitas Muhammadiyah Tasikmalaya. 